\title{
The politics of promoting social cash transfers in Uganda:
}

DOI:

10.1111/dpr.12474

\section{Document Version}

Accepted author manuscript

Link to publication record in Manchester Research Explorer

\section{Citation for published version (APA):}

Hickey, S., \& Bukenya, B. (2019). The politics of promoting social cash transfers in Uganda: The potential and pitfalls of 'thinking and working politically' . Development Policy Review. https://doi.org/10.1111/dpr.12474

\section{Published in:}

Development Policy Review

\section{Citing this paper}

Please note that where the full-text provided on Manchester Research Explorer is the Author Accepted Manuscript or Proof version this may differ from the final Published version. If citing, it is advised that you check and use the publisher's definitive version.

\section{General rights}

Copyright and moral rights for the publications made accessible in the Research Explorer are retained by the authors and/or other copyright owners and it is a condition of accessing publications that users recognise and abide by the legal requirements associated with these rights.

\section{Takedown policy}

If you believe that this document breaches copyright please refer to the University of Manchester's Takedown Procedures [http://man.ac.uk/04Y6Bo] or contact uml.scholarlycommunications@manchester.ac.uk providing relevant details, so we can investigate your claim.

\section{OPEN ACCESS}




\section{The politics of promoting social cash transfers in Uganda:}

\section{The potential and pitfalls of 'thinking and working politically'}

Sam Hickey ${ }^{1}$ and Badru Bukenya ${ }^{2}$

\section{Abstract}

Social cash transfer programmes (SCTs) have spread rapidly in sub-Saharan Africa during the last decade, with international development agencies playing a major role in this process. Theoretical advances suggest that transnational policy transfer is most effective when international actors are able to align their proposals with domestic political dynamics. This article examines how the adoption of a 'thinking and working politically' approach enabled donors to shape the uptake of SCTs in Uganda. It investigates what happens when a 'going with the grain' approach is deployed in a context where domestic political dynamics are moving further away from the progressive forms of politics that proponents of social protection in Africa have often heralded.

The article is based on an in-depth qualitative case study of the promotion of SCTs in Uganda. Over 35 key informant interviews were undertaken with all key stakeholders, particularly between 20142016 after the government of Uganda announced a scaling-up of SCTs. The triangulation of these accounts within a rigorous process-tracing methodology enables us to link key turning points in this process to donor strategies and Uganda's changing political settlement.

Donor efforts to promote SCTs in Uganda prospered when a shift was made from a technocratic to a more politically-informed approach in the late 2000s. By employing strategies from the new 'thinking and working politically' agenda, an alignment was eventually achieved between SCTs and Uganda's shifting political settlement, including the president's increased vulnerability to popular pressures and the commercialization of patron-client politics. However, cash transfers have been adopted primarily as a form of clientelism rather than as a strategy for promoting either significant levels of poverty reduction or an improved social contract. This raises questions both about the developmental character of politics in Uganda and the problems that may emerge when donors seek to 'think and work politically' in such contexts.

Keywords: social protection, politics, cash transfers, thinking and working politically, donors, Uganda

\footnotetext{
${ }^{1}$ Sam Hickey (sam.hickey@manchester.ac.uk) is Professor of Politics and Development at the Global Development Institute, University of Manchester, UK.

${ }^{2}$ Badru Bukenya (badrub@gmail.com) is Lecturer in the Department of Social Work and Social Administration at Makerere University, Uganda.
} 


\section{INTRODUCTION}

In August 2013, the president of Uganda issued a letter to the Minister of Gender, Labour and Social Development (MGLSD) that called for an extension of the Senior Citizens' Grant (SCG) project to a 15th district. This was in addition to the 14 districts in which it had been piloted since 2010. The new district was Yumbe, located in the northern part of the country where the president was keen to consolidate his recent gains at the 2011 election. Yumbe was chosen because, earlier in 2013, a delegation of local leaders from the district had directly lobbied the president for their district to be included. The same letter also requested that the Minister of Gender prepare plans for a national roll-out of the cash transfer project, which involves delivering 25,000 Ugandan shillings (c.US\$10) per month to all citizens aged over 65 within the pilot districts. ${ }^{3}$ Taken by surprise, the international donor officials and bureaucrats within MGLSD, who had been at the forefront of promoting social protection in Uganda for a decade, saw this as a major breakthrough. Meanwhile, the same announcement was greeted with a mixture of dismay and anger within the Ministry of Finance, Planning and Economic Development (MFPED).

Following a heated two-hour debate in cabinet, during which the president argued in favour of extending the programme and MFPED officials emphasized the budgetary constraints, the Ministry allocated 2 billion Ugandan shillings to the scheme within the 2014-15 budget. The plot was thickened further by the fact that the Ministry of Gender had also requested financial support for a new Youth Livelihoods Programme, the latest in a long line of pre-election 'handout' projects used to ensure support for the government since the mid-1990s. This programme was allocated 19 billion Ugandan shillings, close to 10 times the amount committed to the cash transfer scheme.

The battle over cash transfers continued during the 2015-16 budget process. The United Kingdom Department for International Development (DFID) had been a leading proponent of social protection in Uganda since the early 2000s and was the main funder of the SCG. With its first phase of funding coming to an end, DFID was keen to extend its commitment but only if the government of Uganda (GoU) would do likewise. In May 2015, DFID wrote to MFPED stating that they would withdraw their support unless government increased its financial contribution to 10 billion Ugandan shillings and accelerate the process of rolling out the SCG. This threat carried particular potency in light of the forthcoming 2016 elections. Working through the coalition of bureaucrats, politicians and civil society actors that it had established to help promote social protection, DFID and its donor allies (UNICEF and IrishAid) embarked on a major lobbying effort within and beyond government to

\footnotetext{
${ }^{3}$ The qualifying age for residents within the Karamoja sub-region is 60 .
} 
emphasize the political dangers of withdrawing a popular programme during election year. With the president now increasingly supportive of the initiative, and even the International Monetary Fund now advocating cash transfers, MFPED's resistance faltered. The 2015-16 Budget Framework Paper included an increased contribution of 9 billion Ugandan shillings for 2015-16 and year-on-year increases to help roll out the SCG to 40 new districts by 2020 .

This process underlines the extent to which the advance of social protection in Africa is a highly political affair that is primarily shaped by the dynamic interplay of transnational policy coalitions and a country's domestic political dynamics (Lavers \& Hickey, 2016). Transnational policy coalitions have long been recognized as critical to processes of policy transfer, operating through alliances of international agencies, policy entrepreneurs, researchers and domestic bureaucrats (Dion, 2008; Stone, 2008). However, existing work on the spread of SCTs (e.g. Cherrier, 2015; Von Gliszczynski, 2015; Simpson, 2017) has tended to underplay the process through which such coalitions are formed and operate, and to exaggerate the extent to which this has involved 'rendering technical' a new policy agenda (Peck \& Theodore, 2015). What is new in the case of Uganda, and also some other cases such as Zambia (Pruce \& Hickey, 2019), is the extent to which donors have now started to deploy a more explicitly politicized approach to their efforts to promote SCTs (Hickey \& Seekings, 2019), as informed by the 'thinking and working politically agenda' (Dasandi et al., 2016). This agenda, which has been promoted by a particular group of development researchers, consultants and donor agencies, encourages development policy actors to not only become better informed about the political economy of the contexts within which they work but also to operate in more politically-informed ways. ${ }^{4}$ This has included calls to 'go with the grain' of domestic political dynamics (e.g. Booth \& Cammack, 2013; Levy, 2014), as a more realistic means of ensuring relevance and progress than promoting idealized solutions.

In this paper we examine what happens when such an approach is adopted in a context where domestic political dynamics are becoming increasingly unfavourable to developmental outcomes. Following recent advances in theorizing the politics of development, we conceptualise these dynamics in terms of a country's 'political settlement', defined as 'the balance or distribution of power between contending social groups and social classes, on which any state is based' (Di John \& Putzel, 2009, p. 4). Political settlements analysis seeks to draw attention to the underlying drivers of elite commitment to development, by examining how changes in the distribution of power amongst

\footnotetext{
${ }^{4}$ See the Thinking and Working Politically Community of Practice website (https://twpcommunity.org/) for further details, and also a recent special edition of Development Policy Review edited by Neil McCulloch on this topic.
} 
elites, and between elites and their followers, can (re)shape incentives around particular policy agendas (Whitfield et al., 2015). As described in detail elsewhere (Lavers \& Hickey, 2016), applying this conceptual approach to the spread of SCTs in Africa moves us beyond the current literature on the expansion of welfare regimes in sub-Saharan Africa, which has tended to either underplay the role of politics by emphasizing the influence of donors (Cherrier, 2015; Simpson, 2017) and income levels (Nino-Zarazua et al., 2012) or of focusing only on formal aspects of politics, such as democracy and good governance. We argue here that such approaches tend to underplay the significance of informal, elite-level politics and to offer limited readings of the ways in which transnational factors and domestic politics interact to produce different levels and types of commitment to social protection, and development more broadly, in Africa.

Our reading of how these interactions have played out in Uganda to date suggests that SCTs have, for the time being at least, largely been captured within the clientelistic logic of Uganda's increasingly personalized political settlement. This contrasts with the suggestion by James Ferguson (2015) that the advance of SCTs elsewhere in Africa reflects the outcomes of rightful claims that hint at a new politics of distribution and the efforts of international development agencies to promote SCTs within a project of. Although cash transfers may eventually come to form part of a citizenshipbased social contract in Uganda, the process that has unfolded so far raises further questions about the increasingly regressive nature of politics in the country (Oloka-Onyango \& Ahikire, 2016), but also about how the new thinking and working politically (TWP) agenda plays out within such contexts. Calls for international donors to 'go with the grain' may need rethinking within certain political contexts. As such, this paper contributes both to a deeper understanding of the politics of building new welfare regimes in Africa and a rethinking of the increasingly politicized efforts of international development agencies to engage with processes of policy engagement.

The article builds on in-depth qualitative research conducted over March-May 2014 and January 2016 in Kampala that involved over 35 key informant interviews with representatives from all major stakeholders: government and donor officials, parliamentarians and civil society actors. This included those who took a leading role in both promoting and resisting social protection from the early 2000s to the present day. ${ }^{5}$ The accounts of the different stakeholders involved were triangulated both with each other and with an analysis of relevant documentation drawn from policy and media reports in order to piece together the process. A rigorous process-tracing methodology (George \& Bennett,

\footnotetext{
${ }^{5}$ Where appropriate, the article covers this early period through research undertaken by the lead author during the late 2000s (Hickey et al., 2009).
} 
2005) was used, whereby we identified key turning points in the process through which cash transfers were adopted and expanded, and then sought to trace these back to a number of key factors and processes associated with Uganda's changing political settlement and donor-government relations. The article now introduces the main dynamics and ideas within Uganda's political settlement, before examining the decade-long campaign to promote SCTs in Uganda. The final two sections analyse the causal mechanisms at work here in relation to transnational factors and Uganda's shifting political settlement, and discuss the implications both for the politics of social assistance and welfare regimes in Africa and the 'thinking and working politically' agenda that has become prominent in international development in recent years.

\section{SHIFTING DYNAMICS OF UGANDA'S TRANSNATIONALIZED POLITICAL SETTLEMENT}

On taking power in Uganda in 1986, Yoweri Museveni's National Resistance Movement (NRM) moved swiftly to try and rebuild state-society relations and promote development in a country badly damaged by two decades of civil strife and authoritarian rule. The NRM's capacity to maintain stability and implement development reforms was closely shaped by its effort to build a broad-based ruling coalition that was inclusive of most elite factions and the country's rural base (GoloobaMutebi \& Hickey, 2013; Lindemann, 2011). The exception that proves this rule is the north of the country, in that the rebel insurgency and related deepening of poverty that characterized this region during the first decades of NRM rule reflected a failure to incorporate northerners into the ruling coalition (Lindemann, 2011). Senior bureaucrats with close links to the president also played an important role, particularly those within the Ministry of Finance charged with maintaining the macro-economic stability that helped underpin impressive levels of pro-poor growth from the late 1980s onwards (Mosley, 2012). Uganda's political settlement during the first decade of NRM rule was 'dominant developmental' in character (Khan, 2010), with the ruling coalition facing little challenge from either excluded elites or lower-level factions in implementing its programme of reforms.

However, the return of elections in 1996 heralded a shift regarding the distribution of power within Uganda's political settlement. The campaign-based decision by President Museveni to implement universal primary education set in place a populist strategy of distributing public goods in return for political loyalty, particularly in rural areas. When senior NRM politicians broke away to form a credible opposition prior to the 2001 elections, governance became increasingly personalized and driven by short-term moves to secure popularity, as with the abolition of graduated tax in 2001 and the process of 'districtization' (Green, 2010). After the closely fought 2006 elections, the president's 
'poverty tours' were deployed as a personalized means of securing loyalty through listening to local concerns, offering handouts and promising further goods upon re-election. This mode of 'inflationary patronage' (Barkan, 2011) reached a new level of intensity at the 2011 elections, when money was poured into rural areas to secure the vote (Izama \& Wilkerson, 2011), particularly in the previously oppositional north. This strategy has been broadly successful in political terms: although the opposition Forum for Democratic Change ran the NRM increasingly close in the 2001 and 2006 elections, its support fell away in 2011 as the north swung behind the NRM (Conroy-Krutz \& Logan, 2012). With other powerful players exiting the ruling coalition in the run-up to the 2016 elections, the president secured over 60 per cent in a heavily disputed poll that involved ever rising levels of vote buying (Golooba-Mutebi \& Hickey, 2016).

This weakening of Uganda's 'dominant party' settlement has considerably reduced the ruling coalition's capacity and commitment to deliver development (Golooba-Mutebi \& Hickey, 2013). By the mid-2000s these shifting political dynamics converged with a watershed moment in Uganda's political economy, with the country graduating from debt, discovering commercial quantities of oil and signing the Sino-Africa pact. These changes weakened the major influence that international development agencies had had over development policy in Uganda since 1987, and saw the poverty agenda that they had helped promote since the late 1990s sidelined in favour of a more ambitious programme of 'prosperity for all' and 'structural transformation' (GoU, 2010; Hickey, 2013). It was in the midst of these shifting political dynamics in Uganda that international donors started to promote the idea of social protection.

\section{THE GRADUAL POLITICIZATION OF PROMOTING SOCIAL PROTECTION IN UGANDA: 2002-15}

The process that led to the government of Uganda adopting higher levels of social protection by 2015 fell into three main phases, and was characterized by a move by international development organisations from seeking to render technical social protection as a solution to specific problems in Uganda (Li, 2007), to a more politically informed strategy. The first phase, between 2002 and 2005, involved a technocratic and only partially successful effort by often competing donor agencies to lever social protection onto Uganda's development policy agenda. From 2006, a more coherent group of donor agencies, led by DFID, adopted a politically attuned strategy that garnered greater success, most notably through gaining approval to start implementing a pilot SCT programme. The third phase, from 2011 onwards, involved social protection increasingly moving from the policy to the political agenda, including through a direct move by donors 'working politically' to use the 
electoral incentives provided by the 2016 poll to secure increased financial commitments from government for SCTs.

\section{Promoting social protection via Uganda's poverty agenda (2002-05)}

...that (in 2002) was when they sold us the idea of social protection. The World Bank was organizing training, they and DFID recommended SRM training in Paris. I went along with officials from Ministry of Finance and Office of Prime Minister. So that's how we started ... got plan approved in 2004, and got it into the last Poverty Eradication Action Plan (interview with MGLSD official, 17 February 2014).

International efforts to promote social protection in Uganda began in 2002, when the World Bank held a training workshop on its 'social risk management' (SRM) approach to social protection for civil servants. A DFID advisor who had attended the workshop then sought to promote an alternative approach, hiring an advisory team of UK-based academics to promote a more transformative policy agenda amongst some of the same Ministry of Gender officials that the Bank had already trained (Devereux \& Sabates-Wheeler, 2004). DFID sought to secure a focus on social protection within Uganda's flagship 'poverty eradication action plan', which was then undergoing review. It established a 'social protection task force', which used seminars and studies conducted by the advisory team to try and persuade sectors to include a focus on social protection in their strategic plans.

This strategy achieved marginal gains, with the World Bank Social Protection specialist admitting in 2005 that 'Mainstreaming has been a struggle' (interview, October 2005). Social protection interventions were mentioned in the second PEAP (2005-8) but did not become budgetary priorities thereafter. Donors failed to engage powerful players from MFPED and the political elite, and although a small cadre of MGLSD civil servants became highly committed to the agenda during this period, the ministry lacked the political clout or technical capacity to wield wider influence. Donor efforts were also undermined by a lack of coordination between the main players involved. 


\section{Towards a more politically attuned strategy of promoting social protection (2006-10)}

From around 2006-7, DFID adopted a more politicized approach to promoting social protection, strongly informed by a political economy study that it had commissioned to inform their strategy. ${ }^{6}$ Its conscious effort to build a coalition in support of social protection in Uganda was adapted to target more influential players, from MFPED in particular. Senior bureaucrats and politicians were taken on study tours, informal lobbying was undertaken with ministers over breakfast meetings and political allies were nurtured to ensure that briefings on social protection were delivered at cabinet retreats and NRM conventions. Efforts to secure support within civil and political society were extended, including support for the Uganda Social Protection Platform in 2008 and the use of media channels to popularize the idea of social protection.

The shifting politics of aid was an enabling factor here, with the arrival of Paris Declaration principles around donor coordination and harmonization leading to a more coordinated approach. DFID became the sector lead on social protection and, with the Bank focusing on developing a national social protection strategy, DFID worked with Irish Aid and UNICEF to establish a pilot SCT project. Advisors from these three agencies gained strong institutional support from their respective agencies, freeing them to invest heavily in policy engagement efforts and ensuring that, when senior figures visited from headquarters, the case for social protection was taken to the highest levels of government. The professional qualities of the advisors and the fact that DFID-Uganda was able to provide resources and technical assistance in a responsive and flexible manner, helped keep the process moving.

By the mid-late 2000s, social protection was becoming a global policy agenda (Hickey \& Seekings, 2019), supported by a growing 'epistemic community' providing 'scholarly argumentation and scientific justification for "evidence-based" policy formulation' on social protection (Stone, 2008, p. 32). DFID employed researchers from the DFID-funded Chronic Poverty Research Centre (CPRC) to help coordinate efforts to promote social protection and assist with pilot project design. This process was managed by Development Research and Training (DRT), a Ugandan-based NGO, which was also funded by DFID to undertake advocacy work on social protection. In September 2008, CPRC and DRT organized a major international conference in Entebbe to showcase the feasibility and effectiveness of social protection, drawing a large audience that included leading figures from the ministries of finance and gender.

\footnotetext{
${ }^{6}$ The DFID office in Uganda has engaged with the 'thinking and working politically' agenda on a regular basis since the late 2000s, as indicated by its commissioning of several political economy analysis studies, both of the country as a whole and of specific sectors.
} 
This more politicized approach seemed to be achieving progress. Having attended the Livingstone conference in March 2006 and visited the Kalomo cash transfer project, ministers and officials from MGLSD and MFPED agreed to DFID's proposed focus on cash transfers. A memorandum of understanding between DFID and government was signed in around September 2006 and design workshops were held in February and March 2007. The plans to scale up the policy were approved by the minister of MGLSD in May and the specific pilot design was approved in June 2007. ${ }^{7}$ However, when DFID tried to transfer funds to MGLSD in August 2007, they were blocked by the then minister of finance, Dr Ezra Suruma, who had played a leading role in devising the ruling party's manifesto for the 2006 election. The return of multi-partyism in 2005 led the NRM to invest more heavily than usual in its manifesto, with the end of debt and rise of oil further emboldening it to wrest control of the development policy agenda away from western donors and their focus on poverty. Entitled 'Prosperity for All', the manifesto set out a more ambitious and productivist agenda that would directly inform the next national development plan. In July 2007, the month before the minister blocked the transfer of funds, reports appeared in the press claiming characterizing the scheme as 'handouts' and an expensive waste of money. As one proponent of social protection working in Uganda at the time noted:

...back in 2007 when the ministry of gender first requested permission from cabinet to implement the programme, they were rejected. The feeling in cabinet was that social protection would lead to dependence, and was not sustainable, it was seen as welfare hand-outs and government didn't want to give such... (interview with authors, March 2014).

However, by 2009 the stand-off had been resolved and cabinet had given its approval for the roll-out of the pilot cash transfer programme. This was partly fortuitous, in that the new minister of finance appointed in 2008, Syed Bbumba, had previously been minister of gender and was sympathetic to the social protection agenda. Importantly, advocates for social protection had also shifted their discursive approach towards a closer alignment with dominant elite ideas:

\footnotetext{
${ }^{7}$ The plan that emerged was to develop six pilots in a regionally representative selection of Uganda's poorest districts, which would target the poorest 10 per cent of households. The design was influenced to some extent by the Orphans and Vulnerable Children programme in Kenya, and transfers would include supplements for children and older people. Selection would be via a mix of community participation and proxy means testing, one cross-checking the other. The cash would be delivered through the financial system and post offices, rather than government channels.
} 
So what we did was that we redefined the programme around vulnerability of certain groups of people, old people, orphans and disabled...we stopped talking about poverty and started talking about vulnerability and social exclusion ... so when we re-articulated the programme that way, cabinet approved it. So I think that is the first political lesson we learnt (interview with aid advisor, March 2014).

Influenced by the political economy study that DFID had commissioned, this new approach to 'going with the grain' was also apparent in the process of programme design. For example, the level of transfer was calibrated to ensure that recipients would not be able to leapfrog those in higher income deciles for fear of fomenting disharmony in local communities (interview with SAGE programme designer, April 2014). This new approach played well, alleviating elite concerns around giving handouts to and causing dependency amongst the undeserving poor. In June 2010, cabinet approved the establishment of the Expanding Social Protection (ESP) programme, as the project delivery unit for the new cash transfer projects.

\section{Expanding Social Protection in Uganda}

“...the programme (ESP) has been critical: field trips, advocacy meetings, international field trips, a relentless building of the politics.

If it doesn't work after this then ... !" (Interview with bilateral aid official, 18 February 2014.)

The Expanding Social Protection programme lies within MGLSD in administrative terms, although its offices are physically located beyond the main ministry in bespoke premises. Staffed by MGSLD bureaucrats and international staff hired by donor agencies through a private sector company, and heavily dependent on donor financing, ESP operates as a politically attuned version of a standard project management unit: it offers technical support for project implementation and policy development and also works actively to build a stronger political constituency in support of social protection. Whilst efforts have been made to balance these roles, which in any case are often fused, there is a sense that the political aspect of ESP's work has been a priority. ${ }^{8}$

\footnotetext{
${ }^{8}$ ESP has often deployed technical methods to offset political pressures, as when concerns around financial sustainability were raised by the cabinet sub-committee appointed to vet the programme (interview with senior MGLSD Official, 17 February 2014); several such reports are available at http://www.socialprotection.go.ug/. However, the political imperative has sometimes overridden the technical aspects of ESP's work, as in March 2013, when an economist staff member was moved
} 
ESP was responsible for rolling out the Social Assistance Grants for Empowerment (SAGE) programme, a four-year pilot in 14 districts that was supposed to be jointly funded by government and development partners (DFID, Irish Aid and UNICEF), but which received no budgetary allocation from GoU until 2014-15. In Phase One, SAGE had two elements, both of which involved pilot cash transfer programmes in 14 districts selected according to their poverty rankings within the context of broadly representative agro-ecological regions. ${ }^{9}$ These were the Senior Citizens Grant (SCG), involving a transfer of around \$US10 per month to all individuals over 65 in the pilot districts, and the Vulnerable Family Grants (VFG), a means-tested cash transfer to households with limited labour capacity, as identified through a mixture of data-driven and community-based targeting. By 2014 the programme reached over 100,000 beneficiaries, being implemented at the local level through a mixture of parallel structures and staff established by ESP with some oversight from local government officials. ${ }^{10}$

The implementation of the SAGE programme began in April 2011 before a baseline study had been conducted. A retrospective baseline was constructed in September-October 2012, followed by impact evaluations after one and two years of the programme being implemented. ESP exploited the fact that they now had a cash transfer project on the ground, using it extensively to persuade political and bureaucratic elites of the need to maintain and extend the programme. Indeed, ESP was encouraged by one minister (who had himself been taken on a DFID-funded study tour to see social pensions in action Lesotho in 2012), to sell SCG as 'a political programme' amongst elites (interview with ESP official, January 2016). This strategy seemed to be effective within the Ministry of Finance: asked what had been the main influence on their newfound support for cash transfers, one MFPED minister answered:

...the field! It is less about reports or study tours than these, seeing direct changes on the ground. See people having meat for Christmas for the first time, school clothes ... there is now respect for these people who used to be cursed for asking you for money. And they are speaking very highly of government now (interview, 17 February 2014).

from his technical role as a research officer to work on advocacy instead (interview with ESP staff member, January 2016).

${ }^{9}$ As of 2015, the SAGE scheme covered 123,153 beneficiaries in 15 districts: Kyenjojo, Kyegegwa, Kiboga, Kyankwanzi, Apac, Kole, Katakwi, Kaberamaido, Moroto, Napak, Nakapiripirit, Amudat, Nebbi, Zombo and Yumbe. By 2019, MGSLD claims that this had been extended to160,000 beneficiaries in 61 districts.

${ }^{10}$ The VGF programme was discontinued at the end of ESP Phase II, with only the SCG rolled out nationally. 
Bureaucrats were more likely to emphasize the technical drivers, stressing that they have been influenced more '... from ESP reports they pass, also they have been able to get a number of ourselves on study tours, training and that has been effective for many of us. These have been best strategies' (senior MFPED official, 17 February 2014).

ESP also worked hard to persuade parliamentarians who had been erstwhile opponents of the scheme. According to one MP:

The first time they (ESP) came to parliament, MPs were hot for them, but they picked the vocal people, took them to trips, ... some of us were then taken to Lesotho, South Africa, Malaysia, got lessons and really appreciated that this support was necessary, did not create laziness, but really helped. So after those visits we caused a platform in cabinet to be formed of all ministers with a social protection agenda; then formed the parliamentary forum as a lobby group .... ESP was very handy (MP, 18 February 2014).

Formed in 2011, the Parliamentary Forum for Social Protection is an informal lobby group of over 60 members and led by a member of parliament from a district covered by the pilot cash transfer programme. The Forum has actively sought to build wider support amongst MPs and also the president:

We have lobbied him directly, although we started with First Lady, as the president seemed to tell us it was consumptive and we should focus on roads. She became a very passionate member of the forum, so from there we even took advantage of the (NRM) retreats that happen every year. So at Kyankwanzi two times we found time to launch this, and by third time he proposed that ministry should prepare a roll-out plan (interview with MP, 18 February 2014). ${ }^{11}$

\footnotetext{
${ }^{11}$ According to one minister, 'Every MP wants it yesterday in their constituency. The First Lady wants it fast-tracked to her region' (interview, 17 February 2014). Kyankwanzi district is an NRM stronghold where the Movement holds its annual retreats and undertakes political education of military and bureaucratic officials.
} 
The real politics of handing out cash in Uganda: Presidentialism, patronage and popular pressures (2013-ongoing)

That one (Yumbe) was chosen because a delegation visited Museveni in his home, he was pushed into a corner. Plus the district had been in conflict, so had suffered a lot. So, politically he instructed that they get it on board (interview with MP, Kampala, 18 February 2014).

By 2013, MGLSD had drafted a National Social Protection Framework and established a cabinet-level inter-ministerial social protection sub-committee (MGSLD, 2013a), but there had been no financial commitment from government's own revenues and the country's new development strategy placed little emphasis on social protection. As such, even government insiders were surprised when President Museveni wrote to the minister of gender in August 2013 requesting that she add a further district (Yumbe) to the SCG pilot programme, and prepare plans for a national roll-out. The letter did not flow directly from a particular lobbying effort by ESP or any new evidence regarding the pilot project's performance. The catalyst was a visit to the president's rural retreat in western Uganda by dignitaries from Yumbe requesting that they also benefit from the programme, which was operational in an adjacent district (interviews with various stakeholders, March-April 2014). Similar delegations had emerged elsewhere, including one from another northern district (Acholi), which had lobbied the minister of gender (interview with MGSLD official, 28 February 2014), and more formal lobbying groups were also emerging, such as the Akole Older Persons Association (interviews with MPs, April 2014). The pressure seemed to be telling: during a celebration of Older Persons Day in October 2013, the president repeated what he termed 'a personal commitment' to roll out the programme to the rest of the country.

The announcement was received with predictably different responses within government. MFPED officials were clearly upset at having to work this new commitment into the next budget priorities, and both the minister and senior bureaucrats opposed the extension on the grounds of cost, financial sustainability and the lack of fit with the government's development strategy (RoU, 2010). A visibly angry senior MFPED technocrat told us that:

... it is not that social protection is wrong, but at the first stage in economic development do you start bringing those issues as a matter of prioritization? So, should I spread resources off UPE, USE into social protection? Those are the choices and trade- 
offs we have to think about. Should I stop roads and infrastructure for social protection? (Interview, 18 February 2014.)

Finance ministry officials were frustrated that their hands have been tied because donors had managed to establish the programme as 'a political fact on the ground', realizing that by now it had become 'politically entrenched ... once you've started you can't go back on it'. Some were also concerned that cash transfers were likely to be used to fuel political clientelism, particularly in the run-up to the 2016 elections. This fear was further fuelled by the fact that the request for increased expenditure on cash transfers came directly alongside a new initiative from the same ministry, namely the Youth Employment Programme (MGSLD, 2013b), widely seen to be a pre-election 'handout' to help secure electoral support for the regime in 2016.

By now a gap had opened up in the Ministry of Finance, largely between politicians who had started to see the political logic of cash transfers, and technocrats, who were concerned with issues of affordability and sustainability. The main exceptions were the then minister, Maria Kiwanuka, who did not sit as a parliamentarian and who sided with her technical staff, and technocrats involved in the ministry's research department, with whom the growing international evidence on social protection had proved influential. As one technocrat noted, '... the politicians are keen, it is helpful for them, they ride on it in their constituencies, because it gives them some political capital in those 14 districts' (interview with MFPED official, 17 February 2014). This struggle between the technocrats and politicians reached the highest levels. There was a heated two-hour debate in cabinet leading up to the 2014-15 budget, during which the president argued in favour of extending the programme and MFPED officials repeatedly emphasized the budgetary constraints (interview with senior MFPED official, January 2016). During the exchange, the president admitted to having been lobbied directly by senior officials from the main agencies and diplomatic missions supporting the programme, namely the UK and Ireland. At this point, the technocrats seemed to have at least limited government's financial exposure: as one MFPED official noted, 'We are only giving 2 billion shillings, not even 10 per cent. We do not have a plan to take on the recurrent expenditures' (senior MFPED official, 17 February 2014). The president himself seemed to accept that there were fiscal limits to rolling out cash transfers, drawing attention to this constraint even whilst making political capital from the programme:

As you know, we committed to provide a Senior Citizens Grants programme to support all older persons in the NRM manifesto. This programme is now being implemented in 
15 pilot districts, with Yumbe district being the most recent addition. Our plan is to gradually extend the programme to more districts in the whole country as resources become available. (speech by president in Yumbe, 1 October 2014, International Day of Older Persons).

The 2015-16 budget struggle: past the point of no return?

... It has a lot of political implications, the moment you start (cash transfers) you have to continue. If you withdrew it from people, it could be protests, voting, people will definitely reset the government. So we will scale up, but only to the limit (senior MFPED official, 17 February 2014).

By 2014, DFID had made plans to extend their support for the Expanding Social Protection Programme for a second five-year phase, but was insistent that government should take on a greater share of the financial burden. In November 2014, MFPED wrote to MGLSD suggesting that they would increase GoU's commitment to 10 billion Uganda shillings for 2015-16. Although much less than the 33 billion shillings that MGLSD had initially requested, both MGLSD and DFID seemed content with this. However, as the budget process progressed, MFPED came under pressure to increase expenditures in other directions, including the mounting costs of the forthcoming 2016 elections, and the amount allocated to SCG was reduced by half, to 5 billion Uganda shillings. This was unacceptable to both DFID and Irish Aid. In March 2015 they called a breakfast meeting with leading members of the social protection coalition, including ministers and senior bureaucrats from MGLSD and key parliamentarians, and the influential chair of the budgetary committee (interview with bilateral aid official, 25 January 2016). They agreed that unless GoU increased its commitment back to 10 billion Uganda shillings, the bilateral agencies would withdraw their support for Phase II of SP. With elections due in February 2016, advocates of social protection within parliament and MGLSD were keen to highlight the dangers of closing a politically popular programme at this point.

The social protection coalition began an intense advocacy effort at all levels of political and civil society. Senior DFID officials called a meeting with senior MFPED officials to tell them directly that they would withdraw their support for SCG unless government increased its financial commitment (interview with bilateral aid official, 25 January 2016). DFID-Uganda also found opportunities to target the president and First Lady: DFID's head of office prepared a briefing paper for the British high commissioner to use when meeting the president for their regular briefing and DFID's visiting director of programmes was requested to raise the issue with the First Lady during a visit in February 
2015. The minister of gender wrote to the president, stating directly that they needed $10 \mathrm{bn}$ shillings from Finance for what is 'a political programme' (interview with MGLSD official, January 2016). In the build-up to the budget speech in June 2015, ESP used donor funding to mount a media campaign across television, radio and newspapers in support of extending cash transfers. ESP also provided direct support to the Parliamentary Forum for Social Protection, and in May 2015 parliamentary debates saw those MPs whose districts had the pilot programme extol its virtues and those MPs in constituencies without it demand that it be extended to them. Forum members held meetings in every region and encouraged district leaders to implore government to roll out the SCG to all parts of the country (interview with member of parliament, January 2016). According to one MGLSD official based within the ESP Secretariat,

... when it was the day to pass the budget, the Parliamentary Committee on Social Development had met with the Budget Committee and made it very clear that we could not lose this programme at a political time such as this. MPs said unanimously that you put this with 10bn, or we do not pass the budget (interview, January 2016).

According to one senior MFPED official,

Parliament exerted its powers: SAGE is very popular, everyone in rural areas wants to associate with SAGE, so when we went to parliament they forced us to increase. It was a combination of donor threats to withdrawal and parliament. It was a condition (interview, January 2016).

By now, even the IMF was advocating SCTs as a sensible fiscal strategy in Uganda, leaving the same senior official to lament that: 'We were surrounded from all sides. Even when the IMF talk to us they bring this' (interview, January 2016). MFPED finally agreed to commit 9 billion Uganda shillings for 2015-16, with incremental annual increases for the whole second phase of the project. This commitment, which was written into the Medium-term Expenditure Framework and would see the SCG extended to the 100 poorest old people in 40 new districts by 2020, was sufficient for DFID and Irish Aid to agree to proceed. 


\section{IDEAS AND INCENTIVES: HOW THE NEW POLITICS OF AID CONVERGED WITH UGANDA'S SHIFTING POLITICAL SETTLEMENT}

The government of Uganda's decision to roll out cash transfers flowed from the decade-long and highly politicized efforts of a transnational policy coalition that eventually became sufficiently aligned with the shifting dynamics of Uganda's political settlement. As per the framework introduced earlier (Lavers \& Hickey, 2016), this interplay of transnational factors and the country's domestic political economy involved both incentives, as it offered a new strategy for securing electoral popularity that fitted with the ruling coalition's increasingly financialized mode of political clientelism, and, to an extent, ideas, most notably around issues of vulnerability and deservingness. Here we analyse the main characteristics of this convergence, identifying the political settlement dynamics and ideational struggles at play and also the tensions that can arise when development agencies start to 'think and work politically' in such contexts.

\section{Political settlement dynamics and ideas in Uganda: cash transfers as a political fix?}

By the mid-2000s, Uganda's political settlement had shifted away from any semblance of 'dominant developmentalism', with the president increasingly deploying personalized forms of patronage to maintain himself in power. The ruling coalition had become increasingly vulnerable to bottom-up demands, particularly from regions where excluded elites had gained electoral popularity. The fact that northern districts were chosen for the political launch of the SCG programme in 2011, and its extension in 2013, is significant in this respect. The north is not only the poorest region in Uganda, but also the one that failed to secure inclusion within the NRM's otherwise broadly based coalition (Lindemann, 2011), and northerners had consistently voted against the NRM in all elections between 1996 and 2006. Aided by the peace process from 2006 onwards, the president undertook a charm offensive in the north, launching new initiatives and undertaking 'poverty tours' to the region that often involved handing out cash to local groups. This strategy had become an increasingly prevalent part of Uganda's political landscape. The commercialization of democracy that characterized the 'bought' elections of 2011 (Izama \& Wilkerson, 2011) reached still greater heights at the 2016 elections, with the president's entourage directly involved in distributing public resources to voters. The cash transfer scheme thus fitted well with the form of political clientelism increasingly deployed by the ruling coalition to maintain itself in power.

The sense that cash transfers received presidential support primarily as a political rather than a developmental strategy is underlined by the ways in which they have been adopted, designed and 
resourced. First, cash transfers were adopted as a result of political pressure, rather than through the formal policy process, and little effort has since been made to integrate social protection within the logic of the national development strategy. ${ }^{12}$ This stands in stark contrast to the ways in which social protection has been directly incorporated into the productivist strategies being pursued in the 'dominant developmental' political settlements of Ethiopia and Rwanda (see Lavers 2019a, 2019b). Second, the fact that the latest roll-out will benefit the 100 eldest pensioners in the new districts reflects elite incentives to ensure a wide geographical spread for the purposes of political popularity, rather than a concern with pro-poor project design. Finally, the Senior Citizens Grant has been awarded a far lower budgetary allocation than other handout programmes targeted at even more politically significant groups, which further underlines the sense that programmes rolled out by the Ministry of Gender are weighted according to their relative contribution to political, rather than developmental, objectives. The Youth Livelihoods Programme, also delivered by MGLSD, was awarded 80 billion Ugandan shillings in 2015-16, compared to 9 billion allocated to the SCG. Even after the current roll-out is completed in 2020, SCG will only have reached less than half of the country's districts ( 40 of over 100 ) and an estimated total of 226,085 beneficiaries. ${ }^{13}$

Seen in this light, Uganda's 'commitment' to social protection emerges as a somewhat half-hearted and instrumental embrace of yet another form of vote-buying clientelism, rather than an ideological form of developmentalism. Nonetheless, the struggle over social protection in Uganda has involved ideas as well as incentives. The transnational policy coalition had to engage in a discursive battle of ideas to get social protection onto the policy agenda in Uganda, both in terms of normative beliefs and cognitive ideas around evidence (Schmidt, 2008). Proponents had to overcome the paradigmatic belief amongst Uganda's ruling elite that it is wrong to offer 'handouts', particularly to able-bodied people who might then become dependent on them. ${ }^{14}$ As detailed above, cabinet only approved the cash transfer pilot in 2009, when the policy coalition changed their discourse from a focus on poverty to vulnerability, and particularly older persons. This discourse was also employed by the

${ }^{12}$ After the 2016 elections, the president directed government to focus on 23 strategic priorities until 2021, none of which referred to social protection (as accessed 9 March 2017, at: http://www.statehouse.go.ug/media/speeches/2016/06/23/strategic-guidelines-and-directives-term2016-2021).

${ }^{13}$ Even if one assumes that the 100 eldest pensioners in any given district were poor, this means the SCG would by 2020 directly reach around 0.56 per cent of the 34.6 per cent of Uganda's citizens currently estimated to be living below the international extreme poverty line (World Bank, 2016). ${ }^{14}$ This belief runs deep in Uganda: according to Mosley (2012), President Museveni initially rejected the World Bank's proposal to offset the social costs of adjustment in the mid-1990s, saying that his government did not give 'handouts', whilst other research points to the emphasis given to the 'productive poor' in Uganda's development policy regime (Hickey, 2005). Even some supporters of the current cash transfer scheme argue that age of recipients should be raised to 70 , on the basis that some over-65s are fit enough to work (interview with MPs, February 2014). 
president during one of his early engagements with the programme, in the northern district of Nebbi:

My government therefore aims to restore the dignity of our senior citizens, empower them to participate in social and community life and enable them to continue supporting their families, through in particular the provision of Senior Citizens Grants (President Museveni, Nebbi, International Women's Day 2012/Launch of SAGE).

These findings underscore the significance of understanding the ideational dimensions of institutional reforms both in general (Schmidt, 2008) and with regards state-society relations in subSaharan Africa (Hagmann \& Peclard, 2010). Interestingly, our findings suggest that normative ideas had much greater importance than scientific evidence in this process; for example, there is little evidence that evaluation-based data helped secure the growth of political commitment to cash transfers in Uganda, a finding that contrasts with the case of Zambia (see Pruce \& Hickey, 2019). The first official evaluation of SAGE had not been published when the president wrote his letter urging a scale-up of the old age pension, and this was an important source of contention with finance ministry officials, one of whom noted in 2014 that, 'We need to see more on the impact. But we are waiting for that impact evaluation that they are doing' (interview with MFPED official, 19 February 2014). It is striking that donor agencies had promoted a scheme so vigorously, despite little evidence being available as to whether it was actually achieving its objectives. This, and the underlying struggle over who should be in control of Uganda's development agenda, suggests that the new 'thinking and working politically' agenda may already be generating unforeseen consequences.

\section{'Going with the grain'? The trade-offs of thinking and working politically in clientelist contexts}

The international effort to promote social protection in Uganda represents something of a test case for the 'thinking and working politically' (TWP) agenda that has become increasingly popular within some development agencies since the early 2000s (Dasandi et al., 2016). DFID was an early adopter of this political turn (Chhotray \& Hulme, 2009), and its deployment of several TWP strategies promoted by development academics (including the authors of this article) has directly shaped the ways and extent to which social protection has been adopted in Uganda. As advocated by leading proponents of the TWP agenda (Booth \& Unsworth, 2014), DFID's decision to use political economy analysis led it to build a strong 'coalition for change' based around actors from political as well as civil society, and to align its discursive strategy with elite ideas around deservingness. This attempt to 'go with the grain' (Booth \& Cammack, 2013; Levy, 2014), included efforts to align cash transfers 
with incentives as well as ideas, as with the significant push for scaling up SCTs as 'a political programme' in the run-up to the 2016 election. Although strategies to render social protection technical were also employed $(\mathrm{Li}, 2007)$, the political strategy was generally paramount. ${ }^{15}$ We discuss the implications of this approach in relation to tensions between the TWP agenda and questions of country ownership and partnership, and the implications of 'going with the grain' for pro-poor politics.

The potential contradictions between the TWP agenda and Paris Declaration principles of country ownership and partnership have already been noted. For Fisher and Marquette (2016), the use of political economy analysis by donors usually runs counter to the notion of country ownership; this is because of the often highly secretive way in which it is conducted and deployed by donors as a form of risk analysis that fails to involve governments in identifying either the problems to be addressed or solutions to be promoted. So, whilst donors were seeking to lever social protection onto the debtrelated poverty eradication action plan, political and technocratic elites were seeking to move Uganda away from the donor-driven poverty agenda in favour of a more nationally-owned and productivist development strategy (RoU, 2010). It could be argued that donors were building on the pro-poor mandate of the Ministry of Gender, and of civil society and citizens in Uganda more broadly, although given the non-existent focus on social protection amongst such actors prior to external intervention, this seemed to have been a fairly latent form of ownership.

Donors' own mandate of promoting poverty reduction is also a factor here. There is no doubt that the agencies and individuals that formed the social protection coalition in Uganda were highly committed to improving the lives of poor people in Uganda, highly knowledgeable about the policy agenda and worked extremely hard to secure a well-designed programme for the country. However, transnational actors, like African political elites, act in accordance with incentives as well as ideas, and it has not always been apparent that the poverty agenda has always been the primary driver of donor activities in this case. It may be going too far to suggest, as one senior government official did, that 'social protection is here for DFID to get prestige' (interview, 18 February 2014). Nonetheless, it needs to be acknowledged that aid agencies such as DFID and others have placed a lot of reputational value on their promotion of social protection and that promoting new policy agendas

\footnotetext{
${ }^{15}$ This stands in contrast to the case of Zambia, where there was a more balanced emphasis on building the technical as well as political case for cash transfers (Pruce \& Hickey, 2019). In Zambia robust evaluative data was used to persuade erstwhile opponents of the effectiveness of social cash transfers, particularly those within the finance ministry tendency. This may mean that it will prove more difficult to disentangle SCTs from political logics in Uganda than in Zambia.
} 
that get taken up by governments is a highly incentivized activity within donor agencies that is likely to generate clashes with the principles of country ownership.

More worrying, is the sense that in adopting a TWP approach, donors may have undermined the pro-poor potential of cash transfers in Uganda. The decision to target older persons, for example, is more understandable on the grounds of political and technical feasibility than in distributional terms, and actually contradicted a DFID-funded study that found targeting by vulnerability in Uganda would have more pro-poor results than targeting by age. ${ }^{16}$ The size of the transfer itself was also limited to prevent those recipients in the poorest income deciles moving beyond those in higher deciles, again (as noted earlier) for reasons that were partly political. The limited evidence available to date from official programme evaluations suggests that the SAGE programme has had little impact on poverty rates, although it was performing favourably regarding the subjective wellbeing of recipients (OPM, 2014). The final evaluation of the programme's first phase, which only captured two years of the programme's impacts, notes that the programme had been '... marginally pro-poor, meaning that poorer households increased their welfare proportionally more than wealthier households', and was unable to identify positive outcomes with regards to education or health (OPM, 2016, p. 2). More positive impacts were identified with regard to households being able to retain and build their productive assets, and helping to increase the self-perceived dignity of elderly beneficiaries by reducing their dependence on others (ibid., p. 8). According to the report,

The fact that the SAGE transfer has not significantly impacted areas beyond basic consumption implies that it is unlikely to prove transformative: it has made an often vital difference to beneficiaries' lives, but due to the relatively low value of the transfer, its potential to alter the welfare trajectories of households over the longer term is somewhat curtailed (OPM, 2016, p. 12).

Even small improvements in the wellbeing of households are clearly to be welcomed, and it remains too soon to properly evaluate the extent to which the programme will have greater benefits over the longer term, particularly if the size of the transfer is increased. ${ }^{17}$ The concern is that the

\footnotetext{
${ }^{16}$ DFID produced this study at the request of MFPED in December 2007. Although this analysis provided the basis for MGLSD to prepare a cabinet memorandum in March 2008 that requested permission to implement a vulnerability-targeted social transfer programme, this decision was later altered in favour of a focus on older persons as a more politically acceptable solution.

${ }^{17}$ There is certainly a case to be made that having something of this nature on the ground that is better than having nothing at all, although some critics might question the value of programmes whose primary contribution could be to help keep a particular government in power.
} 
politicized nature of the roll-out announced in 2015 does not seem to be taking the programme in a particularly pro-poor direction.

A final concern would be whether the 'going with the grain' approach adopted here has undermined the potential for cash transfers to have a progressive impact on pro-poor politics, in line with claims that social protection may help empower citizens and improve state-society relations (Molyneux, 2016). ${ }^{18}$ It is too early to judge whether SCTs will become fully captured within the clientelistic strategies designed to secure political support in Uganda or whether they will start to become institutionalized in ways that help to forge a citizenship-based social contract (Ferguson, 2015). Programme founders certainly had this ambitious objective in mind from the outset, insisting that 'Citizen' formed part of the programme's titular name and later going to great lengths to stimulate public debate around the rights of the older persons and other vulnerable groups to social protection. Efforts have also been made to ensure that the implementation process was channelled to recipients in ways that avoided capture within local clientelist networks. However, the final evaluation of the programme's first phase found that the intervention 'has not produced a change in people's perceptions of the social contract, or their ideas about the duties of citizens and the responsibilities of the state' (OPM, 2016, p. 12), a finding which supports the wider sense that cash transfers have, so far at least, been more aligned with the politics of clientelism than of citizenship in Uganda. ${ }^{19}$

\section{CONCLUSION}

The increased commitment of the government of Uganda to social protection directly reflects the success of a transnational policy coalition in aligning this new policy agenda with some of the ideas and incentives that characterize Uganda's shifting political settlement. Tilting the balance from a technical to a political mode of policy influencing helped persuade erstwhile opponents of the case for cash transfers, although the decisive push came from the political dynamics generated by getting a pilot cash transfer project on the ground. These resonated with Uganda's shift towards a more competitive and weakly dominant form of political settlement, particularly the logics of Museveni's increasingly populist brand of vote-buying clientelism. However, whilst handing out cash to older persons may offer the ruling coalition a useful means of appeasing some lower-level demands,

\footnotetext{
${ }^{18}$ We recognize that not all approaches to 'thinking and working politically' necessarily involve 'going with the grain', with some more actively promoting progressive changes to the grain of 'actually existing politics' itself. ${ }^{19}$ Local-level research suggests that SCG recipients view the grant as a 'gift' rather than as a 'right' (Angucia \& Katusiimeh, 2015).
} 
particularly within previously oppositional regions, but it currently remains a marginal strategy, both in terms of the ruling coalition's wider mechanisms for securing votes and legitimacy, and the wider productivist development agenda. This may of course change over time, and what seems clear now is that cash transfers have become part and parcel of the political landscape in Uganda: according to one government minister, 'It is more difficult to stop social protection than if you stopped UPE' (interview with government minister, 17 February 2014).

That achieving this took a highly politicized effort by development agencies raises questions concerning the fit between Paris Declaration principles of 'ownership' and 'partnership' and the new 'thinking and working politically' agenda. Attempting to 'go with the grain' may also incur trade-offs concerning the pro-poor and politically progressive character of interventions, and raises concerns regarding what happens when development agencies take on board exhortations made by development academics such as ourselves to operate in more politically attuned ways. Aligning policy agendas with dominant interests and ideas may render interventions politically acceptable in contexts such as Uganda, but at the cost of further embedding clientelist logics and doing little to address distributional problems. These problems flow more fundamentally from the shifting nature of the political settlement in Uganda than from the contemporary nature of aid per se, and it is difficult to see how cash transfers could have been established in this context without the kind of approach adopted by donors here. However, it may be that shifting the focus from promoting particular policy instruments to instead promoting the longer-term drivers through which social protection has historically become embedded within African polities may prove useful (Iliffe, 1987; Hickey, 2008). Avoiding the populism that cash transfers can easily help foment and become trapped within perhaps involves paying greater attention to building 'fiscal contracts' that involve attention to issues of taxation as well as distribution (Teichmann, 2008). This would involve external actors thinking and working politically with a much longer timeframe in mind with regards historical processes of state, citizenship and capital formation in Africa. Such a project would likely go beyond a new politics of distribution (cf. Ferguson 2015), and encompass efforts to build higher levels of bureaucratic capacity and domestic revenue generation, whilst also encouraging the forms of structural transformation that have historically encouraged political elites in Africa to invest more fully in social protection. ${ }^{20}$

First submitted March 2019 Final draft accepted May 2019

\footnotetext{
${ }^{20}$ See Hickey (2008) on these long-term political and political economy drivers of increased political commitment to social protection in Africa.
} 


\section{Acknowledgements}

The authors are grateful for the comments and insights of Tom Lavers, Stephen Barrett, Jeremy Seekings, Miguel Nino-Zarazua and three anonymous reviewers. In addition we are grateful for comments received at the Development Studies Association Annual Conference 2015, internal seminars at the Global Development Institute and the workshops organised by UNU-WIDER in Mexico City, February 2016. We are particularly grateful to the many individuals who contributed their time and insights to this project, and who are too numerous to list by name here. Any errors remain our own.

The research for this paper was undertaken within the Effective States and Inclusive Development Research Centre, based at The University of Manchester, UK, with funding from the United Kingdom Department for International Development. This document is therefore an output from a project funded by UK Aid. However, the views expressed and information contained in it are not necessarily those of, or endorsed by the UK government, which can accept no responsibility for such views or information or for any reliance placed on them. This production of this paper was further supported by UNU-WIDER, Helsinki, from its project: 'The Economics and Politics of Taxation and Social Protection'. The work originally appeared in both the ESID and UNU-WIDER working paper series.

\section{References}

Angucia, M., \& Katusiimeh, M. W. (2015). 'Political Economy of Social Protection Uptake in Uganda'. Prepared for Partnership for African Social and Governance Research (PASGR) Research Project on 'Political Economy of Universal Social Protection Policy Uptake in Africa'.

Barkan, J. (2011). Uganda: Assessing Risks to Stability. Washington, DC: Centre for Strategic and International Studies.

Booth, D., \& Cammack, D. (2013). Governance for Development in Africa: Solving Collective Action Problems. London: Zed Books.

Booth, D., \& Unsworth, S. (2014). 'Politically Smart, Locally Led Development - Discussion Paper'. London: Overseas Development Institute.

Brooks, S. M. (2015). Social protection for the poorest: The adoption of antipoverty cash transfer programs in the Global South. Politics \& Society, 43(4), 551-582.

Cherrier, C. (2015). 'Examining the Catalytic Effect of Aid on Domestic Resource Mobilisation for Social Transfers in Low-Income Countries'. UNRISD Working Paper Series o 2015-3. Geneva: United Nations Research Institute for Social Development. 
Chhotray, V., \& Hulme, D. (2009). Contrasting Visions for Aid and Governance in the 21st Century: The White House Millennium Challenge Account and DFID's Drivers of Change. World Development, 37(1), 36-49.

Conroy-Krutz, J., \& Logan, C. (2012). Museveni and the 2011 Ugandan Election: Did the Money Matter? The Journal of Modern African Studies, 50, 625-655.

Dasandi, N., Marquette, H., \& Robinson, M. (2016). Thinking and Working Politically: From Theory Building to Building an Evidence Base. DLP Research Paper no 37. Birmingham: Developmental Leadership Program.

Devereux, S., \& Sabates-Wheeler, R. (2004). Transformative Social Protection. IDS Working Paper no 232. Brighton: Institute of Development Studies.

Di John, J., \& Putzel, J. (2009). Political Settlements: Issues Paper. Birmingham: Governance and Social Development Resource Centre, University of Birmingham.

Dion, M. (2008). International organizations and social insurance in Mexico. Global Social Policy, 8(1), 25-44.

Ferguson, J. (2015). Give a Man a Fish: Reflections on the New Politics of Distribution (Durham, NC: Duke University Press).

Fisher, J., \& Marquette, H. (2016). "Empowered patient" or "doctor knows best"? Political Economy Analysis and Ownership. Development in Practice, 26(1), 115-126.

George, A. L., \& Bennett, A. (2005). Case Studies and Theory Development in the Social Sciences. Cambridge, MA: MIT Press.

Golooba-Mutebi, F., \& Hickey, S. (2013). Investigating the Links between Political Settlements and Inclusive Development in Uganda: Towards a Research Agenda. ESID Working Paper no 20. Manchester, UK: Effective States and Inclusive Development Research Centre, The University of Manchester.

Golooba-Mutebi, F., \& Hickey, S. (2016). The master of institutional multiplicity? The shifting politics of regime survival, state-building and democratisation in Museveni's Uganda. Journal of Eastern African Studies, 10(4), 601-618.

Green, E. (2010). Patronage, District Creation, and Reform in Uganda. Studies in Comparative International Development, 45(1), 83-103.

Green, M. (2009). Thinking through Chronic Poverty and Destitution: Theorising Social Relations and Social Ordering. In T. Addison, D. Hulme \& R. Kanbur (eds.), Poverty Dynamics: Interdisciplinary Perspectives. Oxford: Oxford University Press.

Hagmann, T., \& Péclard, D. (2011). Negotiating Statehood: Dynamics of Power and Domination in Africa. John Wiley \& Sons. 
Hickey, S. (2005). The Politics of Staying Poor: Exploring the Political Space for Poverty Reduction in Uganda. World Development, 33(6), 995-1009.

Hickey, S. (2008). Conceptualising the Politics of Social Protection in Africa. In A. Barrientos \& D. Hulme (eds.), Social Protection for the Poor and Poorest: Concepts, Policies and Politics. London: Palgrave.

Hickey, S. (2013). Beyond the Poverty Agenda? Insights from the New Politics of Development in Uganda. World Development, 43, 194-206.

Hickey, S., with Sabates Wheeler, R., Guenther, G., \& Macauslan, I. (2009). Promoting SP \& ST: DFID the Politics of Influencing. Department for International Development Working Paper no 32. London: Department for International Development.

Hickey, S., \& Seekings, J. (2019). Who should get what, how and why? DfID and the transnational politics of social cash transfers. In S. Hickey, T. Lavers, M. Niño-Zarazúa, \& J. Seekings (eds.), The Politics of Social Protection in Eastern and Southern Africa. Oxford: Oxford University Press.

Iliffe, J. (1987). The African Poor: A History. Cambridge: Cambridge University Press.

Izama, A., \& Wilkerson, M. (2011). Uganda: Museveni's Triumph and Weakness. Journal of Democracy, 22(3), 64-78.

Khan, M. (2010). 'Political Settlements and the Governance of Growth-Enhancing Institutions'. School of Oriental and African Studies, London: Unpublished manuscript.

Lavers, T. (2019a). Social protection in an aspiring 'developmental state': The political drivers of Ethiopia's PSNP. African Affairs.

Lavers, T. (2019b). Understanding elite commitment to social protection: Rwanda's Vision 2020 Umurenge Programme. In S. Hickey, T. Lavers, M. Niño-Zarazúa, \& J. Seekings (eds.), The Politics of Social Protection in Eastern and Southern Africa. Oxford: Oxford University Press.

Lavers, T., \& Hickey, S. (2016). Conceptualising the Politics of Social Protection Expansion in Low Income Countries: The Intersection of Transnational Ideas and Domestic Politics. International Journal of Social Welfare, 25(4), 388-398.

Lavers, T. (2019). Social protection in an aspiring 'developmental state': The political drivers of Ethiopia's PSNP. African Affairs. doi.org/10.1093/afraf/adz010

Levy, B. (2014). Working with the Grain: Integrating Governance and Growth in Development Strategies. New York: Oxford University Press.

Li, T. M. (2007). The Will to Improve: Governmentality, Development and the Practice of Politics. Durham and London: Duke University Press. 
Lindemann, S. (2011). Just Another Change of Guard? Broad-based Politics and Civil War in Museveni's Uganda. African Affairs, 110(440), 387-416.

MLGSD. (2013a). 'National Social Protection Policy Framework for Uganda: Enabling All Citizens to Participate in and Benefit from Uganda's Social and Economic Transformation'. October 2013 draft. Kampala: Ministry of Gender, Labour and Social Development.

MLGSD. (2013b). 'Youth Livelihoods Programme'. Kampala: Ministry of Labour Gender and Social Development (MLGSD).

Molyneux, M., with Jones, N., \& Samuels, F. (2016). Can Cash Transfer Programmes Have "Transformative" Effects? The Journal of Development Studies, 52(8), 1743-9140.

Mosley, P. (2012). The Politics of Poverty Reduction. Oxford: Oxford University Press.

Niño-Zarazúa, M., Barrientos, A., Hickey, S., \& Hulme, D. (2012). Social Protection in Sub-Saharan Africa: Getting the Politics Right. World Development, 40(1), 163-176.

Oloka-Onyango, J., \& Ahikire, J. (2016). Controlling Consent: Uganda's 2016 Election. Trenton, New Jersey: Africa World Press.

OPM. (2014). Evaluation of the Uganda Social Assistance Grants for Empowerment (SAGE) Programme: Impact after One Year of Programme Operations 2012-2013. Oxford: Oxford Policy Management; Kampala: Economic Policy Research Centre; Kampala: Department of Anthropology and Sociology, University of Makerere.

OPM. (2016). Evaluation of The Uganda Social Assistance Grants for Empowerment (SAGE) Programme - Impact after Two Years of Programme Operations 2012-2014 Final Report. Oxford: Oxford Policy Management.

Peck, J., \& Theodore, N. (2015). Fast Policy: Experimental Statecraft at the Thresholds of Neoliberalism. Minneapolis: University of Minnesota Press.

Pruce, K., \& Hickey, S. (2019). The politics of promoting social cash transfers in Zambia. In S. Hickey, T. Lavers, M. Niño-Zarazúa, \& J. Seekings (eds.), The Politics of Social Protection in Eastern and Southern Africa. Oxford: Oxford University Press.

Republic of Uganda. (2010). Uganda National Development Plan: Growth, Employment and Socioeconomic Transformation for Prosperity. Kampala: National Planning Authority.

Schmidt, V. A. (2008). Discursive Institutionalism: The Explanatory Power of Ideas and Discourse. Annual Review of Political Science, 11(1), 303-326.

Simpson, J. P. (2017). Do donors matter most? An analysis of conditional cash transfer adoption in Sub-Saharan Africa. Global Social Policy, 18(2), 143-168.

Stone, D. (2008). Global Public Policy, Transnational Policy, Communities and Their Networks. The Policy Studies Journal, 36(1), 19-38. 
Whitfield, L., Therkildsen, O., Buur, L., \& Kjær, A. M. (2015). The Politics of African Industrial Policy: A Comparative Perspective. Cambridge: Cambridge University Press.

World Bank. (2016). Uganda Poverty Assessment 2016. Washington, DC: World Bank. 